\title{
Cnidae sizes in the two morphotypes of the giant Caribbean anemone Condylactis gigantea (Actiniaria: Actiniidae)
}

\author{
Ricardo González-Muñoz ${ }^{1 *}$, Carlos Hernández-Ortiz ${ }^{2}$, Agustín Garese ${ }^{1}$, Nuno Simões ${ }^{3}$ \\ \& Fabián Horacio Acuña ${ }^{1}$ \\ 1. Laboratorio de Biología de Cnidarios, Instituto de Investigaciones Marinas y Costeras, Facultad de Ciencias Exactas \\ y Naturales, Universidad Nacional de Mar del Plata-CONICET, Rodríguez Peña 4046, 7600 Mar del Plata, Argentina; \\ ricordea.gonzalez@gmail.com, agustingarese@gmail.com, facuna@mdp.edu.ar \\ 2. Departamento de Acuacultura y Biología Marina, Escuela de Ciencias Aplicadas del Mar, Universidad de Oriente, \\ Núcleo Nueva Esparta, Boca de Río, Isla de Margarita, Venezuela; cehernanort@gmail.com \\ 3. Unidad Multidisciplinaria de Docencia e Investigación en Sisal (UMDI-Sisal), Facultad de Ciencias, Universidad \\ Nacional Autónoma de México (UNAM), Puerto de Abrigo, Sisal, 97356, Yucatán, México; International Chair of \\ Coastal and Marine Studies in Mexico, Harte Research Institute, Texas A\&M at Corpus Christi, TX, USA; Laboratorio \\ Nacional de Resiliencia Costera (LANRESC); ns@ciencias.unam.mx
}

Received 15-II-2018. Corrected 29-V-2018. Accepted 27-VI-2018.

\begin{abstract}
The sea anemone Condylactis gigantea is an ecologically important member of the benthic community in coral reefs of the tropical Atlantic, and displays two morphotypes with respect to the color in their tentacular tips: the green tip morphotype and the pink/purple tip morphotype. Although some molecular and ecological differences have been found between these morphotypes, no other morphological distinctions have been reported, and currently both are still considered a single taxonomic species. In the present study, we perform an exploration on the variability in the size of cnidae between these two morphotypes and performed statistical analyses to compare the 10 categories of cnidae from specimens hosted in the Cnidarian Collection of Gulf of Mexico and Mexican Caribbean, of the Universidad Nacional Autónoma de México, which were previously collected in several coral reefs localities of the Yucatán Peninsula. Results reveal no significant variation in cnidae size between the two morphotypes, but significant variations were found within each morphotype. In addition, we update the composition of the cnidom of C. gigantea, and the utility of the size of cnidae to distinguish between morphotypes or closely related species is discussed. Rev. Biol. Trop. 66(3): 1055-1064. Epub 2018 September 01.
\end{abstract}

Key words: Cnidaria; Anthozoa; cnidom; coral reefs; morphotype; Condylactis gigantea.

The giant Caribbean sea anemone Condylactis gigantea (Weinland, 1860) (Actiniaria, Actiniidae) is one of the most common and well-known actiniarian species that inhabits in coastal and coral reefs environments of the Western Atlantic Ocean, and is distributed from Bermuda to southeast Brazil, and along the Gulf of Mexico and the Caribbean Sea (González-Muñoz, Simões, Sánchez-Rodríguez, Rodríguez, \& Segura-Puertas, 2012). This species is an ecologically important member of the benthic community providing habitat for several species of caridean cleaner shrimps (Silbiger \& Childress, 2008; Colombara, Quinn, \& Chadwick, 2017), as well as symbiotic associations with some species of Caribbean fishes (Hanlon \& Kaufman, 1976; Hanlon \& Hixon, 1986). Moreover, this species is also recognized as an important source of biologically active compounds (e.g. Billen, Debaveye, Béress, Garateix, \& Tytgat, 2010; Romero et al., 2010; Santos et al., 2013) and, due to its brightly colors and attractive forms, it is much appreciated in the aquarium trade (Chiappone, Swanson, \& Miller, 2001; Sheridan, Fautin, \& Garret, 2015). 


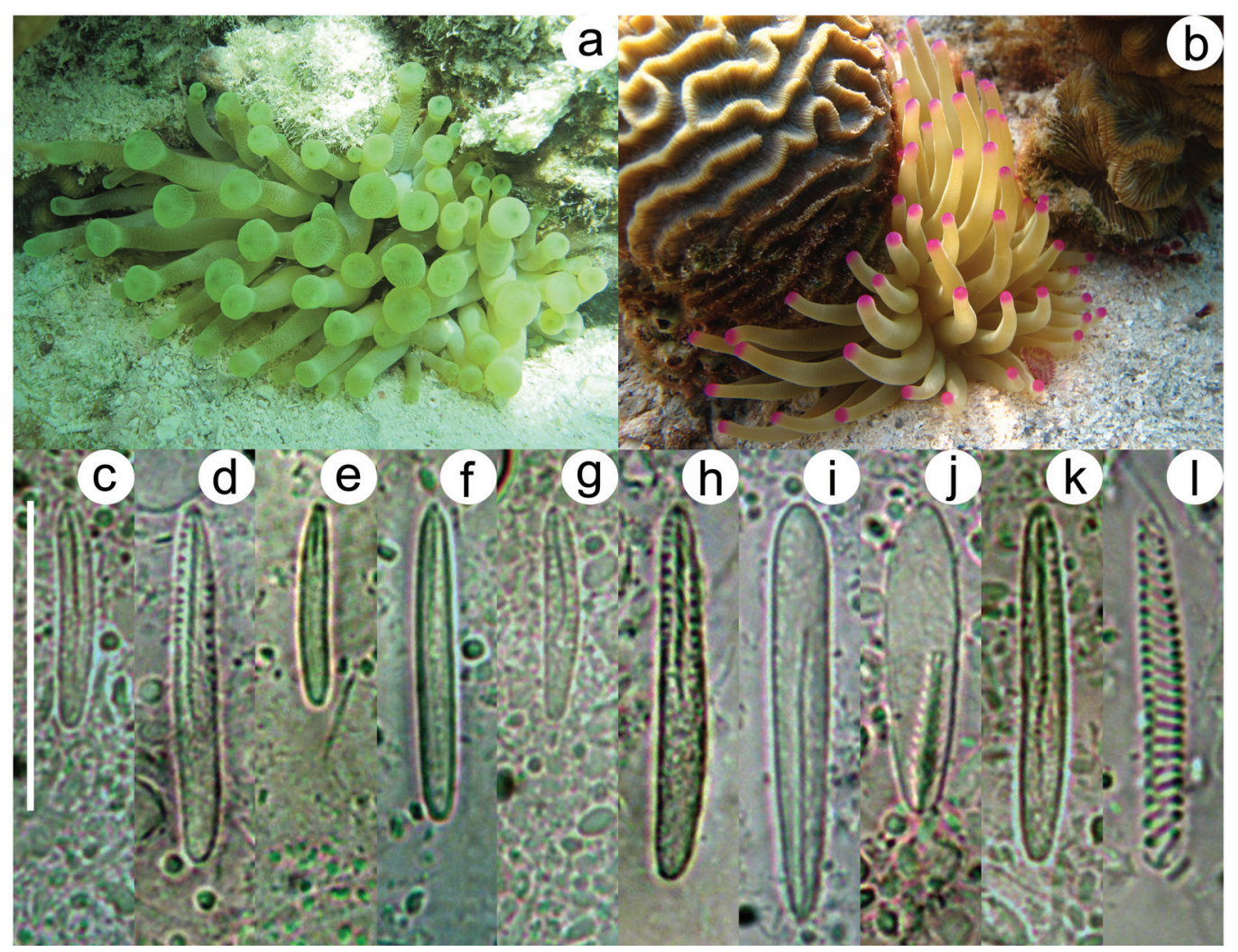

Fig. 1. Morphotypes of Condylactis gigantea: a. Green morphotype. b. Pink/Purple morphotype. Cnidom of C. gigantea per tissue type. Actinopharynx: c. small basitrich. d. large basitrich. Column: e. small basitrich. f. large basitrich. Filaments: g. small basitrich. h. large basitrich. i. microbasic $b$-mastigophore. j. microbasic $p$-mastigophore. Tentacles: k. basitrich. l. spirocysts.

Condylactis gigantea displays two main morphotypes, particularly with respect to color in the tentacular tips, which can be categorized as the green tip (Fig. 1A) and the pink/purple tip morphotypes (Fig. 1B), although some individuals with whitish, yellowish, or bluish tentacular tips can be also rarely found. Previous genetic comparisons with DNA sequence data have found some differences between these two morphotypes from specimens of different depths and reef areas, as well as differences in UV absorbance capacities, suggesting reduced gene flow and ecological differentiation among the green and the pink/purple morphotypes at a small geographic scale (Stoletzki \& Schierwater, 2005). Other differences between these morphotypes have also been observed on personality and habitat segregation (Hensley,
Cook, Lang, Petelle, \& Blumstein, 2012). However, no other morphological differences between these two morphotypes have been reported and both are currently considered a single taxonomic species.

Despite the size of cnidae alone is not necessarily a conclusive taxonomic character to differentiate between species due to its variability within conspecific individuals (Fautin, 2009; Garese, Carrizo, \& Acuña, 2016), some studies consider them as an additional specific taxonomic characteristic to distinguish between closely related species, but only when these differences are accompanied by other morphological or ecological distinctions (Fautin, 1988). Some studies including quantitative analyses of the size of cnidae to distinguish between closely related species or between 
morphotypes suggests results of two opposite sorts. Some studies found significant statistical differences in cnidae sizes comparisons (e.g. Allcock, Watts, \& Thorpe, 1998; Watts \& Thorpe, 1998; Manchenko, Dautova, \& Latypov, 2000; Watts, Allcock, Lynch, \& Thorpe, 2000), while other attempts did not find statistical support to clearly separate species or morphotypes based on cnidae size differences (e.g. SoléCava \& Thorpe, 1987; Chintiroglou \& Karalis, 2000; González-Muñoz et al., 2015; GonzálezMuñoz, Garese, Tello-Musi, \& Acuña, 2017).

In the present study, we performed an exploration on the variability in the size of cnidae and statistically analyze them to compare between the two morphotypes of $C$. gigantea, from preserved specimens of the Collection of Cnidarians of the Gulf of Mexico and Mexican Caribbean, of the Universidad Nacional Autónoma de México (UNAM). In addition, we update the composition of the cnidom of $C$. gigantea, and discuss about the utility of the size of cnidae to distinguish between closely related species or between morphotypes.

\section{MATERIALS AND METHODS}

Five specimens of each of the two morphotypes were selected from the Collection of Cnidarians of the Gulf of Mexico and Mexican Caribbean Sea (Registration code: YUC-CC-254-11) of the Unidad Multidisciplinaria de Docencia e Investigación - Sisal (UMDI-Sisal) at the UNAM. Specimens were selected based on the photographs of the living specimens which are included in each record of the collection. All specimens were collected in coastal coral reefs localities along the Yucatán Peninsula (Appendix). Pedal disc diameter and column height of the samples were measured from living specimens (Appendix); however, comparisons between morphotypes were made regardless the size of the specimens or their reef localities. Four squash preparations were obtained from the main tissue types $\left(\sim 1 \mathrm{~mm}^{3}\right)$ of each specimen. Cnidae capsules were analyzed from tissues from tentacles, actinopharynx, mesenteric filaments, and mid column. Terminology follows Östman (2000). From each of the four squash preparations, the length and width of 30 undischarged capsules (replicates) of each type of cnidae were randomly measured using DIC microscopy $1000 x$ oil immersion (following Williams, 1996). Cnidae preparations were deposited in the same Cnidarian collection.

Cnidae samples were ordered in a bidimensional space using principal component analysis (PCA). Differences in ordination given by morphotype and individual specimens within each morphotype were analyzed using a permutational multivariate analysis of variance (PERMANOVA) procedure (Anderson, 2001). Differences among cnidae size were analyzed for each type of cnidae and tissue separately. The PERMANOVA procedure was applied on resemblance matrices based on the Euclidian distance between samples. Although length and width of the capsules were in the same measurement unit, data were normalized prior to analyses. The statistical model used was given by: $Y_{i j k l}=M_{i}+I(M)_{j(i)}+T_{k}+M T_{i k}+I(M) T_{j(i) k}+e_{i j k l}$, where $Y$ is the response matrix with $n$ samples $*$ $P=2$ variables (number of columns: length and width); $M$ is a fixed factor representing morphotype (with two levels); $I$ is a random factor representing individuals nested in $M$ (with five levels); $T$ is the fixed factor representing type of cnidae and is orthogonal to $M$ and $I ; M T$ and $I(M) T$ are corresponding interactions terms; and $e$ is the residual matrix. Permutation procedures were applied to obtain appropriate distributions for the pseudo-F statistic under the null hypothesis. All analyses were performed using 999 permutations of residuals under the reduced model. The experimental design was balanced in every case, and the partitioning of variation was achieved so that the statistic test represents the proportion of the variation in the bi-dimensional cloud that is explained by the source of variation being tested. All analyses were performed using the software Primer v6 (Clarke \& Gorley, 2006). 


\section{RESULTS}

Three hundred cnidae capsules per each specimen were measured, to a total of 3000 capsules. The same five types of cnidae, distributed in 10 categories regarding the size class and tissue location, were found in all samples of $C$. gigantea, regardless of morphotype. The cnidom of both morphotypes includes basitrichs (two size categories), microbasic $p$-mastigophores, microbasic $b$-mastigophores, and spirocysts (Fig. 1C, Fig.1D, Fig. 1E, Fig. 1F, Fig. 1G, Fig. 1H, Fig. 1I, Fig. 1J, Fig. 1K and Fig. 1L).

The PCA ordination of samples from all tissue types showed that the first principal component explained a higher percentage of variability in all cases (Table 1). The first principal component represents the cnidae length, while the second principal component is related with the cnidae width (Fig. 2 and Fig. 3). Overall, no significant variation in cnidae size between the green and pink/purple morphotypes was found in any of the comparisons made (Table 1). However, significant variations in cnidae size were found within each morphotype, in all cases.

\section{DISCUSSION}

Previous taxonomic revisions on C. gigantea include only three types of cnidocysts as part of their cnidom: basitrichs, microbasic $p$-mastigophores, and spirocysts (Carlgren, 1949, 1952; González-Muñoz et al., 2012). In the present study, we report the additional finding of microbasic $b$-mastigophores in the mesenterial filaments of all specimens examined of $C$. gigantea. Microbasic $b$-mastigophores have not been previously reported in other species of the genus Condylactis, but are common in several species classified within the family Actiniidae and the superfamily Actinioidea Rafinesque, 1815 (Rodríguez et al., 2014). Thus, although its encounter could be expected, also contribute to a better understanding of the cnidae variability within the genus Condylactis and within Actiniidae.

Regarding statistical analyses of the size of cnidae, significant variability was found between specimens within each morphotype, as have been also observed in other studies (e.g. Allcock et al., 1998; Watts et al., 2000; González-Muñoz et al., 2015, 2017; Garese, Carrizo, \& Acuña 2016). However, the comparison between the green and pink/purple morphotypes reveals no statistical variation, agreeing with previous morphological revisions which suggest that there are no other morphological differences between the morphotypes, besides the variability in the tentacular tip coloration (González-Muñoz et al., 2012). In other species of sea anemones the variation between morphotypes occurs also

TABLE 1

Probability associated with pseudo-F values obtained through restricted permutations of the residuals of MANOVA models applied to the similarity matrices (Euclidean distance) calculated from cnidae sizes (length and width)

\begin{tabular}{llcccc}
\multicolumn{1}{c}{ Tissue } & \multicolumn{1}{c}{ Cnidae type } & PC1 \% & PC2 \% & $P($ morph $)$ & $P($ Ind[Morph]) \\
Actinopharynx & Small basitrichs & 59.7 & 40.3 & 0.865 & $0.001^{*}$ \\
& Large basitrichs & 63.1 & 36.9 & 0.949 & $0.001^{*}$ \\
Column & Small basitrichs & 56.1 & 43.9 & 0.827 & $0.001^{*}$ \\
& Large basitrichs & 67.1 & 32.9 & 0.709 & $0.001^{*}$ \\
& Small basitrichs & 59.2 & 40.8 & 0.265 & $0.001^{*}$ \\
& Large basitrichs & 53.8 & 46.2 & 0.620 & $0.001^{*}$ \\
\multirow{3}{*}{ Tentacles } & Microbasic $b$-mastigophores & 55.5 & 44.5 & 0.270 & $0.001^{*}$ \\
& Microbasic $p$-mastigophores & 50.7 & 49.3 & 0.301 & $0.001^{*}$ \\
& Basitrichs & 56.6 & 43.4 & 0.479 & $0.001^{*}$ \\
\hline
\end{tabular}

\footnotetext{
$*$ = Significant values.
} 


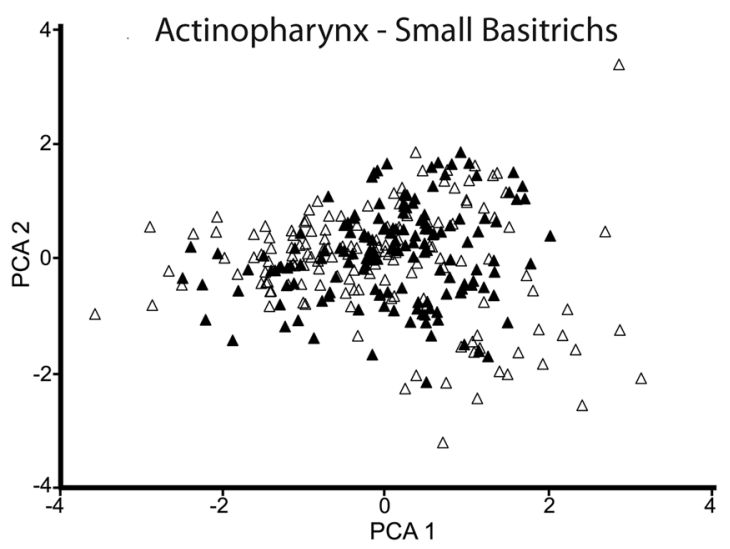

Actinopharynx - Large Basitrichs
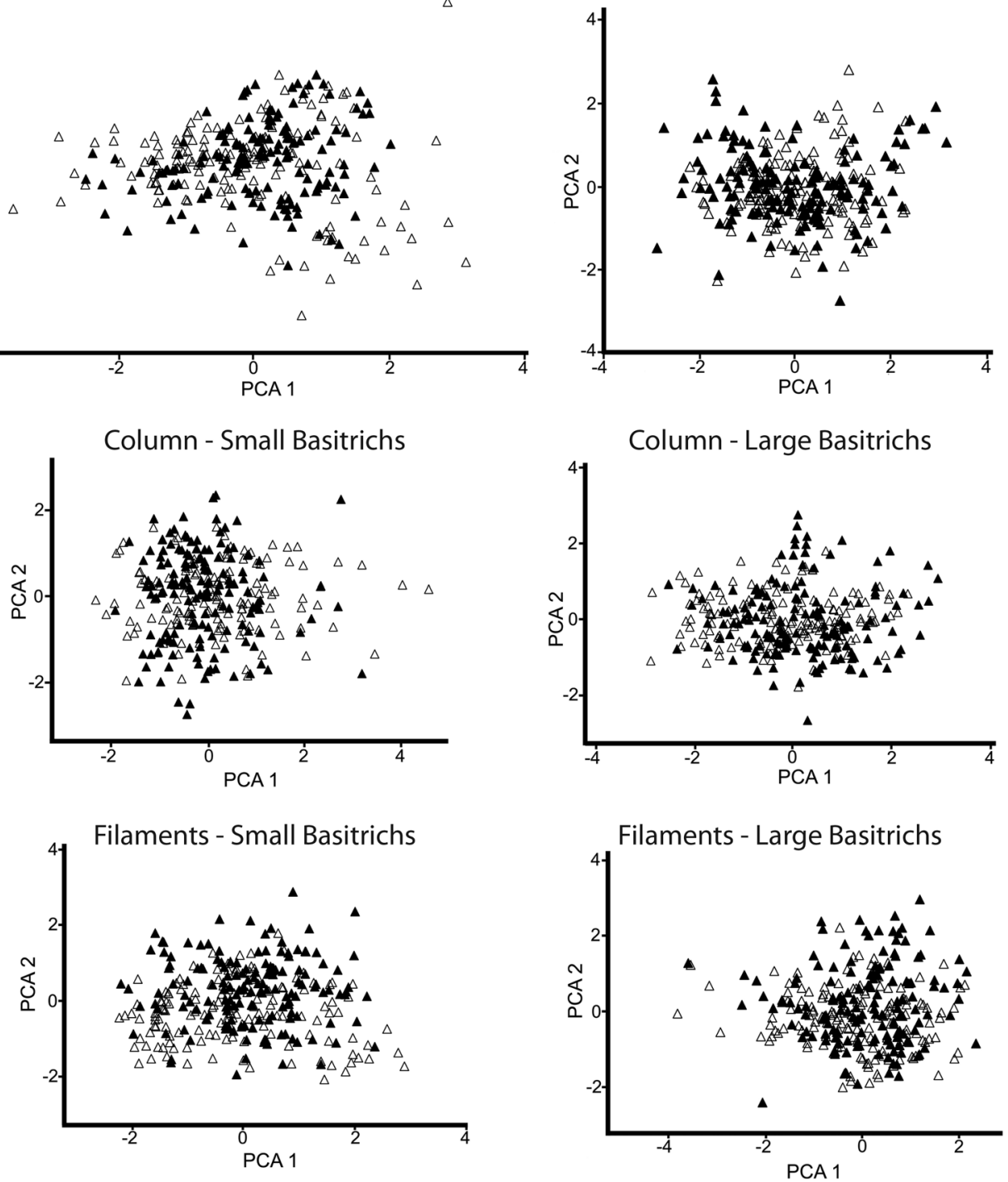

Fig. 2. Principal component analyses of cnidae data (length/width) from actinopharynx, column, and filament tissues; data from all specimens examined. Data of size of cnidae of the Green morphotype are represented by unfilled triangles and those of the Pink/Purple morphotype by black triangles.

anatomical structures besides the coloration, such as the tentacular variation of Phymanthus crucifer (Le Sueur, 1817) (González-Muñoz et al., 2015); or the variation in the cnidae size range in Lebrunia coralligens (Wilson, 1890) (González-Muñoz et al., 2017). Furthermore, although our analyses only focused in the comparison between morphotypes regardless samples body size or reef locality of origin, results suggest a high degree of stability in the size of cnidae of $C$. gigantea.

Intraspecific variation of cnidae size is a known fact in sea anemones (Garese et al., 2016) and it has been suggested that could be a result of several factors as distinct body sizes or weights (e.g. Chintiroglou \& Simsiridou, 
Filaments - Microbasic b-mastigophores
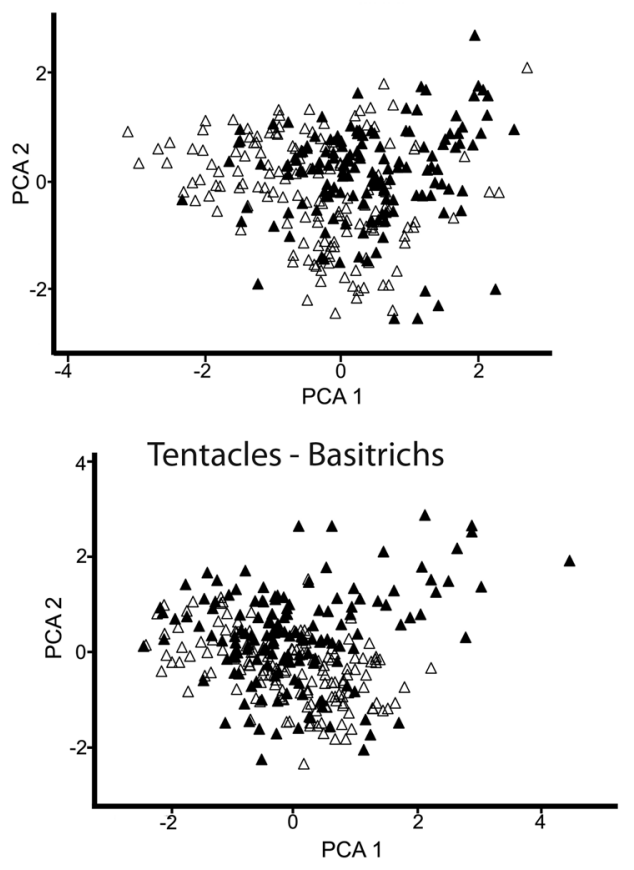

Filaments - Microbasic $b$-mastigophores
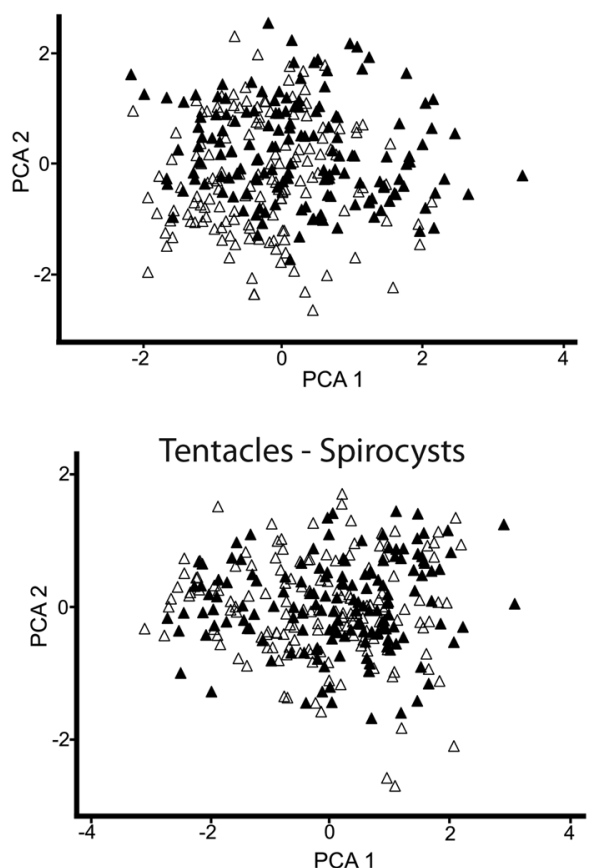

Fig. 3. Principal component analyses of cnidae data (length/width) from filaments and tentacles tissues; data from all specimens examined. Data of size of cnidae of the Green morphotype are represented by unfilled triangles and those of the Pink/Purple morphotype by black triangles.

1997; Karalis \& Chintiroglou, 1997; Acuña, Excoffon, \& Ricci, 2007), different age or stage of maturity (e.g. Doumenc, Chintiroglou, \& Foubert, 1989; Allcock et al., 1998), and different locations and depths (e.g. Karalis \& Chitiroglou, 1997; Zamponi \& Acuña, 1994), among others. However, no variability is revealed when other data sets are compared, like those from the distinct morphotypes of $C$. gigantea, or those from the morphotypes of P. crucifer (González-Muñoz et al., 2015). In some instances, significant variability in the size of cnidae could be found in comparisons between morphotypes. For example, GonzálezMuñoz et al. (2017) found significant variability in 10 of the 14 cnidae size categories in the comparison between the two morphotypes of $L$. coralligens; however, differences in the size of cnidae were much greater when comparing each of the two morphotypes with its congener Lebrunia neglecta Duchassaing \&
Michelotti, 1860, and in all of the 14 cnidae size categories compared.

It seems that at some point in the addition of samples from more specimens to the comparisons, all the variability in cnidae size of a particular species could be gathered, evoking then to the classical questions: Could it be that all the presumed gathered variability in cnidae size of a particular species results in a pattern or range that can be used as a reliable taxonomic diagnostic feature? If so, how many specimens and samples would be required to gather all the complete cnidae size variability of a particular species?

Furthermore, although statistical comparisons of size of cnidae from distinct morphotypes have been done between individuals from different coloration patterns (Allcock et al., 1998; Watts \& Thorpe, 1998; Chintiroglou \& Karalis, 2000; Watts et al., 2000), distinct anatomical structures (González-Muñoz et al. 
2015, 2017); locations (González-Muñoz et al., 2015), subtidal zones or depths (Allcock et al., 1998; Watts et al., 2000), and pedal disc sizes (e.g. Chintiroglou \& Karalis, 2000), results have been variable and presumably dependent on the species treated, and even on the statistical methods implemented (Garese et al., 2016).

Coloration in sea anemones is due mainly to the presence of various types of carotenoids and/or carotenoproteins (LeBoeuf, McCommas, Howe, \& Tauber, 1981a; LeBoeuf, McCommas, \& Howe, 1981b), which are basically obtained by prey consumption (Fox, 1979). However, some studies suggest that the color variability in sea anemones cannot be solely explained by differential assimilation of carotenoids from the diet (Fox \& Pantin, 1941; Dunn, 1977; LeBoeuf et al., 1981a), but that color polymorphism is due to the variation in the proportions of carotenoids which is the result of modifications in the carotenoid biotransformation pathway that is under genetic control (Dunn, 1977; LeBoeuf et al., 1981a, b; McCommas \& LeBoeuf, 1981). LeBoeuf et al. (1981a) even suggest that the differences in the carotenoid proportions can serve as markers of genetic differentiation among populations, or even among close related species (LeBoeuf et al., 1981b).

Stoletzki \& Schierwater (2005) observed that the green and the pink-purple morphotypes of $C$. gigantea differed significantly in UV-B absorbance. They also compared the ribosomal ITS1-5.8S-ITS2 region in the two morphotypes from specimens of two distinct coral reefs habitats about $5 \mathrm{~km}$ apart, the lagoon and the forereef. They found two distinct ITS variants that were present in both habitats, which showed an association with the two color morphotypes in the lagoon, but not in the forereef. Their results suggest some but inconclusive genetic differences between the two colors morphotypes of $C$. gigantea. Thus, the genetic distinction of the two morphotypes remains obscure.

The comparison in the proportion of carotenoids between the two morphotypes, and the implementation of other molecular markers could offer new insights to elucidate the variability in the tentacle colorations of $C$. gigantea .

\section{ACKNOWLEDGMENTS}

The first author is grateful to the Programa de Becas Postdoctorales of the Comisión Nacional de Ciencia y Tecnología (CONACyT, Grant 232318). All specimens were collected under consent of Mexican law, collecting permit approved by Comisión Nacional de Acuacultura y Pesca (Number 07332.250810.4060). We thank to Edlin Guerra-Castro (UNAMSisal) for valuable support in the statistical analyses, and to Alejandro Cordova (UNAMFES-I) for his help in the field work. This work was partially financed by grants to NS from the Harte Research Institute with funds from the Harte Charitable Foundation, and CONABIO- NE018.

\section{RESUMEN}

Tamaños de cnidae en dos morfotipos de la anémona gigante del Caribe Condylactis gigantea (Actiniaria: Actiniidae). La anémona Condylactis gigantea es un miembro ecológicamente importante de la comunidad bentónica en arrecifes de coral del Atlántico tropical, y exhibe dos morfotipos con respecto al color de las puntas de sus tentáculos: el morfotipo de puntas verdes y el morfotipo de puntas rosadas/púrpuras. Aunque se han encontrado algunas diferencias moleculares y ecológicas entre estos morfotipos, no se han reportado otras distinciones morfológicas, y actualmente ambos siguen siendo considerados una sola especie taxonómica. En el presente estudio, realizamos una exploración sobre la variabilidad en el tamaño de los cnidocistos entre estos dos morfotipos y realizamos un análisis estadístico de 10 categorías de cnidocistos a partir de especímenes albergados en la Colección de cnidarios del Golfo de México y Caribe Mexicano, de la Universidad Nacional Autónoma de México, los cuales fueron previamente recolectados en varias localidades arrecifales de la Península de Yucatán. Los resultados no revelan variación significativa en el tamaño de los cnidocistos entre los dos morfotipos, aunque fueron encontradas variaciones significativas dentro de cada morfotipo. Adicionalmente, actualizamos la composición del cnidoma de C. gigantea, y discutimos sobre la utilidad de la talla de los cnidocistos 
para distinguir entre morfotipos o entre especies estrechamente relacionadas.

Palabras clave: Cnidaria; Anthozoa; cnidoma; arrecifes de coral; morfotipo; Condylactis gigantea.

\section{REFERENCES}

Acuña, F. H., Excoffon, A. C., \& Ricci, L. (1997). Composition, biometry and statistical relationships between the cnidom and body size in the sea anemone Oulactis muscosa (Cnidaria: Actiniaria). Journal of the Marine Biological Association of the United Kingdom, 87, 415-419.

Allcock, A. L., Watts, P. C., \& Thorpe, J. P. (1998). Divergence of nematocysts in two colour morphs of the intertidal beadlet Actinia equina. Journal of the Marine Biological Association of the United Kingdom, 78, 821-828.

Anderson, M. J. (2001). A new method for non-parametric multivariate analysis of variance. Austral Ecology, $26,32-46$.

Billen, B., Debaveye, S., Béress, L., Garateix, A., \& Tytgat, J. (2010). Phyla- and subtype-selectivity of $\mathrm{CgNa}$, a $\mathrm{Na}^{+}$channel toxin from the venom of the Giant Caribbean Sea Anemone Condylactis gigantea. Frontiers in Pharmacology, 1, 133, 1-11.

Carlgren, O. (1949). A survey of the Ptychodactiaria, Corallimorpharia and Actiniaria. Kunglia Svenska Vetenskaps Akademiens Handlingar, 1, 1-121.

Carlgren, O. (1952). Actiniaria from North America. Arkiv für Zoologi, 3(3), 373-390.

Chiappone, M., Swanson, D. W., \& Miller, S. L. (2001). Condylactis gigantea - a giant comes under pressure from the aquarium trade in Florida. Reef Encounter, $30,29-31$.

Chintiroglou, C. C., \& Karalis, P. (2000). Biometric investigations on the cnidae of the Aegean colour morphs of Anemonia viridis. Journal of the Marine Biological Association of the United Kingdom, 80, 543-544.

Chintiroglou, C. C., \& Simsiridou, M. (1997). Biometric investigations on the cnidae of the sea anemone Actinia equina mediterranea form I sensu Schimdt, 1972. Israel Journal of Zoology, 43, 5-11.

Clarke, K. R. \& Gorley, R. N. (2006). PRIMER v6: User Manual/Tutorial. PRIMER-E, Plymouth.

Colombara, A. M., Quinn, D., \& Chadwick, N. E. (2017). Habitat segregation and population structure of Caribbean Sea anemones and associated crustaceans on coral reefs at Akumal Bay, Mexico. Bulletin of Marine Science, 93(4), 1-23.
Doumenc, D., Chintiroglou, C., \& Foubert, A. (1989). Variabilité du genre Telmatactis Gravier, 1918 (Actiniaria, Acontiaria, Isophellidae). Bulletin du Muséum National d'Historie Naturelle, 11(1), 5-45.

Duchassaing, P., \& Michelotti, G. (1860). Mémoire sur les Coralliaires des Antilles. Turin, Italy: Imprimerie Royale.

Dunn, D. G. F. (1977). Variability of Epiactis prolifera (Coelenterata: Actiniaria) in intertidal zone near Bodega Bay, California. Journal of Natural History, $11,457-463$.

Fautin, D. G. (1988). Importance of nematocysts to actinian taxonomy. In D. A. Hessinger \& H. M. Lenhoff (Eds), The Biology of Nematocysts (487-500). San Diego, CA, USA: Academic Press.

Fautin, D. G. (2009). Structural diversity, systematics, and evolution of cnidae. Toxicon, 54, 1054-1064.

Fox, D. L. (1979). Biochromy. Natural coloration of living things. California, USA: University of California Press.

Fox, D. L., \& Pantin, F. R. S. (1941). The colours of the plumose anemone Metridium senile (L.) Philosophical Transactions of the Royal Society of London, 574(230), 415-450.

Garese, A., Carrizo, S., \& Acuña, F. H. (2016). Biometry of sea anemone and corallimorpharian cnidae: statistical distribution and suitable tools for analysis. Zoomorphology, 135, 395-404.

González-Muñoz, R., Garese, A., Tello-Musi, J. L., \& Acuña, F. H. (2017). Morphological variability of the "Caribbean hidden anemone" Lebrunia coralligens (Wilson, 1890). Zoomorphology, 136, 287-297.

González-Muñoz, R., Simões, N., Mascaró, M., TelloMusi, J. L., Brugler, M. R., \& Rodríguez, E. (2015). Morphological and molecular variability of the sea anemone Phymanthus crucifer (Cnidaria, Anthozoa, Actiniaria, Actinionidea). Journal of the Marine Biological Association of the United Kingdom, 95(1), 69-79.

González-Muñoz, R., Simões, N., Sánchez-Rodríguez, J., Rodríguez, E., \& Segura-Puertas, L. (2012). First inventory of sea anemones (Cnidaria: Actiniaria) of the Mexican Caribbean. Zootaxa, 3556, 1-38.

Hanlon, R. T., \& Hixon, R. F. (1986). Behavioral associations of coral reef fishes with the sea anemone Condylactis gigantea in the Dry Tortugas, Florida. Bulletin of Marine Science, 39(1), 130-134.

Hanlon, R. T., \& Kaufman, L. (1976). Associations of seven West Indian reef fishes with sea anemones. Bulletin of Marine Science, 26(2), 225-232. 
Hensley, N. M., Cook, T. C., Lang, M., Petelle, M. B., \& Blumstein, D. T. (2012). Personality and habitat segregation in giant sea anemones (Condylactis gigantea). Journal of Experimental Marine Biology and Ecology, 426-427, 1-4. DOI:10.1016/j. jembe.2012.05.011

Karalis, P., \& Chintiroglou, C. C. (1997). Biometric investigations on the cnidae of the rustica-color variety of the sea anemone Anemonia viridis (Förskal, 1775). Israel Journal of Zoology, 43(4), 385-390.

Le Sueur, C. A. (1817). Observations on several species of the genus Actinia; illustrated by figures. Journal of the Academy of Natural Sciences of Philadelphia, 1, 149-154, 169-189.

LeBoeuf, R. D., McCommas, S. A., \& Howe, N. R. (1981b). Coloration in sea anemones - II. Comparative studies on the column carotenoid polymorphism for two species of Bunodosoma (Anthozoa: Actiniaria). Comparative Biochemistry and Physiology Part B, 68(2), 221-224.

LeBoeuf, R. D., McCommas, S. A., Howe, N. R., \& Tauber, J. D. (1981a). The role of carotenoids in the color polymorphism of the sea anemone, Bunodosoma granulifera (Anthozoa: Actiniaria). Comparative Biochemistry and Physiology Part B, 68(2), 25-29.

Manchenko, G. P., Dautova, T. N., \& Latypov, Y. Y. (2000). High level of genetic divergence between sympatric color morphs of the littoral sea anemone Anthopleura orientalis (Anthozoa: Actiniaria). Biochemical Systematics and Ecology, 28, 737-750.

McCommas, S. A., \& LeBoeuf, R. D. (1981). Reduced color polymorphism in a population of Bunodosoma granulifera. Biochemical Systematics and Ecology, 9(4), 329-332.

Östman, C. (2000). A guideline to nematocysts nomenclature and classification, and some notes on the systematic value of nematocysts. Scientia Marina, 64(1), 31-46.

Rafinesque, C. S. (1815). Analyse de la Nature ou Tableau de 1'Univers et des Corps Organisés. Palerme, Italy: Rafinesque, C.S.

Rodríguez, E., Barbeitos, M. S., Brugler, M. R., Crowley, L. M., Grajales, A., Gusmão, L., Häussermann, V., Reft., A., \& Daly, M. (2014). Hidden among sea anemones: The first comprehensive phylogenetic reconstruction of the order Actiniaria (Cnidaria, Anthozoa, Hexacorallia) reveals a novel group of hexacorals. PLoS One, DOI: 10.1371/journal.pone.0096998

Romero, L., Marcussi, S., Marchi-Salvador, D. P., Silva Jr., F. P., Fuly, A. L., Stábeli, R. G., da Silva, S. L., González, J., del Monte, A., \& Soares, A. M. (2010). Enzymatic and structural characterization of a basic
$\mathrm{A}_{2}$ from the sea anemone Condylactis gigantea. Biochimie, 92, 1063-1071.

Santos, Y., Martínez, M., Sandoval, A., Rodríguez, A. A., Falcón, A., Heimer de la Cotera, E. P., Aguilar, M. B., Flores, P., Felix, R., \& Arreguín, R. (2013). Arrhythmogenic effect of a crude extract from sea anemone Condylactis gigantea: Possible involvement of rErg1 channels. Toxicon, 67, 47-54. DOI:10.1016/j. toxicon.2013.02.015

Sheridan, N. E., Fautin, D. G., \& Garret, M. J. (2015). Gametogenesis and reproductive periodicity of the "biologically vulnerable" giant Caribbean sea anemone, Condylactis gigantea, in Florida. Invertebrate Biology, 134(2), 116-128. DOI:10.1111/ivb.12084

Silbiger, N. J. \& Childress, M. J. (2008). Interspecific variation in anemone shrimp distribution and host selection in the Florida Keys (USA): Implications for marine conservation. Bulletin of Marine Science, 83(2), 329-345.

Solé-Cava, A. M., \& Thorpe, J. P. (1987). Further genetic evidence for the reproductive isolation of green sea anemone Actinia prasina Gosse from common intertidal beadlet anemone Actinia equina (L.) Marine Ecology Progress Series, 38, 225-229.

Stoletzki, N., \& Schierwater, B. (2005). Genetic and color morph differentiation in the Caribbean sea anemone Condylactis gigantea. Marine Biology, 147(3), 747754. DOI:10.1007/s00227-005-1620-y

Watts, P. C., \& Thorpe, J. P. (1998). Phenotypic identification of three genetically differentiated morphs of the intertidal beadlet Actinia equina (Anthozoa: Cnidaria). Journal of the Marine Biological Association of the United Kingdom, 78, 821-828.

Watts, P. C., Allcock, A. L., Lynch, S. M., \& Thorpe, J. P. (2000). An analysis of the nematocysts of the beadlet anemone Actinia equina and the green sea anemone Actinia prasina. Journal of the Marine Biological Association of the United Kingdom, 80, 719-724.

Weinland, D. F. (1860). Über Inselbildung durch korallen und Mangrovebüsche im mexikanischen Golf. Württembergische Naturwissenschaftliche Jahreshefte, 16, 31-44.

Williams, R. B. (1996). Measurements of cnidae from sea anemones (Cnidaria: Actiniaria): statistical parameters and taxonomic relevance. Scientia Marina, 60(2-3), 339-351.

Wilson, H. V. (1890). On a new actinia, Hoplophoria coralligens. Studies at the Biological Laboratory of the Johns Hopkins University, 4(6), 379-387.

Zamponi, M. O., \& Acuña, F. H. (1994). La variabilidad de los cnidocistos y su importancia en la determinación de clines. Physis, 49(116-117), 7-18. 


\section{APPENDIX}

Collection code, name, and coordinates of localities, and measures from the specimens examined in the present study

\begin{tabular}{|c|c|c|c|c|c|}
\hline Morphotype & Collection code & $\begin{array}{l}\text { Localities in the Yucatán } \\
\text { Peninsula }\end{array}$ & Coordinates & $\begin{array}{l}\text { Pedal disc } \\
\text { diameter } \\
(\mathrm{mm})\end{array}$ & $\begin{array}{c}\text { Column } \\
\text { height } \\
(\mathrm{mm})\end{array}$ \\
\hline \multirow[t]{5}{*}{ Green tip } & YUC-CC-254-11-000071 & $\begin{array}{l}\text { Majahual Reef, } \\
\text { Quintana Roo, México }\end{array}$ & $\begin{array}{l}18^{\circ} 41^{\prime} 07.4^{\prime \prime} \mathrm{N} \\
87^{\circ} 43^{\prime} 08.2^{\prime \prime} \mathrm{W}\end{array}$ & 43 & 18 \\
\hline & YUC-CC-254-11-000094 & $\begin{array}{l}\text { Alacranes Reef, } \\
\text { Yucatán, México }\end{array}$ & $\begin{array}{l}22^{\circ} 22^{\prime} 56.3^{\prime \prime} \mathrm{N} \\
89^{\circ} 40^{\prime} 57.8^{\prime \prime} \mathrm{W}\end{array}$ & 49 & 41 \\
\hline & YUC-CC-254-11-000207 & $\begin{array}{l}\text { Isla Mujeres Reef, } \\
\text { Quintana Roo, México }\end{array}$ & $\begin{array}{l}21^{\circ} 11^{\prime} 47.8^{\prime \prime} \mathrm{N} \\
86^{\circ} 43^{\prime} 38.1^{\prime \prime} \mathrm{W}\end{array}$ & 39 & 41 \\
\hline & YUC-CC-254-11-000215 & $\begin{array}{l}\text { Punta Nizuc Reef, } \\
\text { Quintana Roo, México }\end{array}$ & $\begin{array}{l}21^{\circ} 08^{\prime} 15.6^{\prime \prime} \mathrm{N} \\
86^{\circ} 44^{\prime} 20.5^{\prime \prime} \mathrm{W}\end{array}$ & 28 & 25 \\
\hline & YUC-CC-254-11-000281 & $\begin{array}{l}\text { Isla Contoy Reef, } \\
\text { Quintana Roo, México }\end{array}$ & $\begin{array}{l}21^{\circ} 27^{\prime} 17.8^{\prime \prime} \mathrm{N} \\
86^{\circ} 47^{\prime} 10.5^{\prime \prime} \mathrm{W}\end{array}$ & 25 & 20 \\
\hline \multirow[t]{5}{*}{ Pink/Purple tip } & YUC-CC-254-11-000085 & $\begin{array}{l}\text { Alacranes Reef, } \\
\text { Yucatán, México }\end{array}$ & $\begin{array}{l}22^{\circ} 22^{\prime} 56.3^{\prime \prime} \mathrm{N} \\
89^{\circ} 40^{\prime} 57.8^{\prime \prime} \mathrm{W}\end{array}$ & 53 & 42 \\
\hline & YUC-CC-254-11-000176 & $\begin{array}{l}\text { Madagascar Reef, } \\
\text { Yucatán, México }\end{array}$ & $\begin{array}{l}21^{\circ} 26^{\prime} 28.8^{\prime \prime} \mathrm{N} \\
90^{\circ} 17^{\prime} 41.6^{\prime \prime} \mathrm{W}\end{array}$ & 40 & 35 \\
\hline & YUC-CC-254-11-000206 & $\begin{array}{l}\text { Punta Cancún Reef, } \\
\text { Quintana Roo, México }\end{array}$ & $\begin{array}{l}21^{\circ} 09^{\prime} 08.5^{\prime \prime} \mathrm{N} \\
86^{\circ} 44^{\prime} 22.5^{\prime \prime} \mathrm{W}\end{array}$ & 36 & 27 \\
\hline & YUC-CC-254-11-000213 & $\begin{array}{l}\text { Isla Mujeres Reef, } \\
\text { Quintana Roo, México }\end{array}$ & $\begin{array}{l}21^{\circ} 11^{\prime} 55.0^{\prime \prime} \mathrm{N} \\
86^{\circ} 43^{\prime} 35.8^{\prime \prime} \mathrm{W}\end{array}$ & 42 & 30 \\
\hline & YUC-CC-254-11-000244 & $\begin{array}{l}\text { Xcalak Reef, } \\
\text { Quintana Roo, México }\end{array}$ & $\begin{array}{l}18^{\circ} 15^{\prime} 53.1^{\prime \prime} \mathrm{N} \\
87^{\circ} 49^{\prime} 33.5^{\prime \prime} \mathrm{W}\end{array}$ & 41 & 31 \\
\hline
\end{tabular}

